\title{
DYNAMIC AND DETERMINANTS OF HIGH TECHNOLOGY EXPORTS IN LATIN AMERICA AND THE CARIBBEAN: A NETWORK AND A PANEL DATA ANALYSIS
}

Jaqueline Moraes ${ }^{1}$

Ivette Luna ${ }^{2}$

\begin{abstract}
This paper seeks to analyze the dynamic and determinants of high technology exports (HTE) to Latin America and the Caribbean, which is carried out on the basis of previous works from the academic literature. To do so, it is used both explanatory Social Network Analysis and the Panel Data modeling, both for the years 2005 to 2015, with data available from the data center of the United Nation Conference on Trade and Development and World Bank Development Indicators, respectively. The results show that when it comes to HTE, Latin America and Caribbean has a minority role inside the network that emerge from exports ties among countries and that inflows of foreign direct investment into the 20 countries of Latin America plus the Caribbean are not significant for explaining the growth of high technology exports. The results also show that past foreign direct investment does not seem to affect changes in high technology exports.
\end{abstract}

Keywords: Latin America; Caribbean; High Tech Exports; Underdevelopment.

\section{RESUMO}

Este artigo procura analisar a dinâmica e os determinantes das exportações de alta tecnologia (HTE) para a América Latina e o Caribe, o que é realizado com base em trabalhos anteriores da literatura. Para tanto, utiliza-se a Análise de Redes para a exploração dos dados e a modelagem de Dados do Painel, ambas para os anos de 2005 a 2015, com dados disponíveis do data center da Conferência das Nações Unidas sobre Comércio e Desenvolvimento e Indicadores de Desenvolvimento do Banco Mundial, respectivamente. Os resultados mostram que, quando se trata de HTE, a América Latina e o Caribe têm um papel minoritário dentro da rede que emerge dos links de exportação entre os países e que os influxos de investimento externo direto nos 20 países da América Latina e Caribe não são significativos para explicar o crescimento das exportações de alta tecnologia. Os resultados também mostram que o investimento externo direto no passado não parece afetar as mudanças nas exportações de alta tecnologia.

Palavras-chave: América Latina; Caribe; Exportações de Alta Tecnologia; Subdesenvolvimento.

ÁREA: 4.1 Economias de Redes

JEL: O54; P45; R12; C23; D85

\footnotetext{
${ }^{1}$ PhD Candidate in Economics at UNICAMP. E-mail: jaquelinemagouveia@gmail.com

${ }^{2}$ Professor in the Institute of Economics at UNICAMP. E-mail: iluna@unicamp.br
} 


\section{INTRODUCTION}

Many theories that try to explain the economic growth of a country has been developed since Smith, Ricardo, Solow, Romer and many others sought to understand what were the sources, forms and effects that determined this phenomenon. One of these theories is export promotion as determinant of growth (BALASSA, 1978; JUNG \& MARSHALL, 1985; ESFAHANI, 1991). Export promotion has been understood as a growth strategy for countries as it signals and fosters increased productivity and economic growth. The focus has been shifting to high-technology trade by studying the relationships between innovation, high-tech international trade and economic performance (TEBALDI, 2011). Innovations are therefore capable of affecting the dynamic economic system and the relative importance that high technology exports have on economic growth. "High technology is often used to refer to firms and industries whose products or services embody advanced and innovative technologies" (SEYOUM, 2005, p.65).

High technology contributes to economic growth in the sense of changing the key factors of success and is now a source of wealth generation as opposed to resource-based industries, predominant in the twentieth century (SEYOUM, 2005). This equates to a transition to a knowledge-based economy, with the level of exports of high technology products as a proportion of manufactured exports. A good measure of the competitiveness of a nation in high technology is based on the presence of substantial exports of the high-tech product sector (SEYOUM, 2004), and these same exports are considered as an important measure of the innovative product (FALK, 2009).

Some studies have been developed to statistically find the determinants of high tech exports (HTE), studies that consider the impacts of higher education, patents, access to computers, size of economy, investment in R\&D, among other factors. "Capability to manufacture and export high technology products in today's competitive global markets basically is an indicator of innovation power of a country" (GÖKMEN and TUREN, 2013, p. 217). However, although many studies have been conducted for developed countries, OECD countries, there is still a gap in such studies for Latin American and Caribbean countries.

To diminish this gap, this paper seeks to analyze, from references and studies already made, the dynamic and determinants of high technology exports to Latin America (Latam) and the Caribbean. To do so, first we analyze the HTE flows in order to evaluate any change on the position of Latam and the Caribbean in this network in 2015 if compared to the one in 2005, both networks built with data from the UNCTAD Statistical Database (UNCTADstat). Second, determinants of HTE are validated with a panel data model which is developed considering Argentina, Bolivia, Brazil, Caribbean, Chile, Colombia, Costa Rica, Cuba, El Salvador, Ecuador, Guatemala, Haiti, Honduras, Mexico, Nicaragua, Panama, Paraguay, Peru, Dominican Republic, Uruguay and Venezuela for the years 2005 to 2015, with data available from the World Bank Development Indicators.

From what follows, this work is divided into four more sections. Section 2 seeks to provide a brief review of the literature on the subject, so as to be able to find out which variables are being used to explain high technology exports. Section 3 tries to explain the methodology used to validate the logic behind the analysis. Section 4 presents the main results and discussions about them. Finally, the final considerations and references used.

\section{LITERATURE REVIEW}

Seyoum (2005) seeks to find the determinants of high technology export levels for developed and developing countries, adopting the conceptual approach known as Porter's Diamond Theory. Porter, according to the author, works on competitiveness based on four independent clusters of external conditions, such as factor conditions, demand conditions, related and support industries, and firm strategy, structure and rivalry. Based on this, the author estimates a multiple cross section regression for 55 countries in the year 2001 in order to explain high technology exports based on three explanatory variables: national technological infrastructure, domestic demand conditions (buyers' sophistication), and foreign direct investment (FDI).

As results, the author finds positive and significant coefficients for the three explanatory variables. Foreign direct investment carries the greatest weight in explaining the growth of high technology exports, 
followed by the sophistication of buyers' needs and technological infrastructure. As a final consideration, the author explores that the development of high technology is not always realized through domestic innovative activity, external technology can be acquired through FDI and productivity gains are generally higher for firms that acquire external technology rather than producing it.

Braunerhjelm and Thulin (2008) study for 19 OECD countries from 1981 to 1999 the relationship between R\&D spending, market size and institutional factors, captured by fixed effects and government spending variables, with high-tech exports. The authors find that R\&D expenditures are positive and significant to explain high technology exports and find no impact of country size on the same, indicating that the home market hypothesis is rejected by the authors.

Tebaldi (2011) analyzes, through panel data with fixed effects, the determinants of high technology exports to around 99 countries from 1980 to 2008, with data taken from Clay and Lee (2010), the Polity IV Project and the World Bank Development Indicators. The author uses explanatory variables such as human capital (average years of schooling of the population over 25 years old), trade liberalization, FDI, investments in physical capital, exchange rates, migration and macroeconomic volatility and as a dependent variable considers two options, the natural logarithm of high-tech exports per worker and high-tech exports as a percentage of manufactured exports.

As a result, the author finds evidence that human capital, FDI, and trade openness are the major impact factors in the performance of a high technology industry in a country in the global market. As final considerations, the author suggests that creating the right incentives for human capital accumulation and openness of the economy for both FDI and international trade helps to create a conducive environment for increasing high technology exports.

Sara et. al (2012) discuss the determinants of high technology exports as a proportion of manufactured exports with the help of seven variables, such as the country's innovative capacity, business sophistication, training and education, technological readiness, infrastructure, business freedom and commercial freedom for 120 countries in 2008. As a result, the authors find that only innovative capacity is significant in explaining the proportion of high-tech products in a country's manufactured exports.

Gökmen and Turen (2013) examine the determinants of high technology export volumes for $15 \mathrm{EU}$ countries using three explanatory variables, namely foreign direct investment, level of economic freedom and the level of human development, through modeling panel data for the years 1995 to 2010. The authors find that the three variables have significant and positive effects on high technology exports.

Based on the studies carried out by the authors, the following section explores the panel data methodology used in this work as a way of ascertaining the determinants of high technology exports to Latin America and the Caribbean.

\section{METHODOLOGY}

According to Fung et al (2016), exports from developing countries have outpaced those from highincome countries during the past few years. And much of this expansion and diversification in trade has been linked to the global fragmentation of production, especially in Asia and Latin America. Therefore, it is important to examine the trends, characteristics and determinants of the trade networks to provide more insight into the regional and global implications in developing countries, especially from our region. And we pretend to do it by using Social Network Analysis (SNA) for the dynamic part, and panel data for the second one on the evaluation of the determinants of HTE.

\subsection{Social network analysis}

SNA is a knowledge field that focuses on a set of actors as well as on the structure that emerges from the ties within them. Although its mathematical foundation has existed for decades (graph theory), it became more familiar since its applications in the sociology field (Scott, 1988) and during the last decade has shown an increase in its application in the social sciences (Serrat, 2017) and in other areas as diverse as psychology, health, business organization, agriculture and Economics (Jackson, 2010).

In general terms, a network can be understood as a structure of relationships that are supposed to be important. Therefore, it is composed of a set of agents -individuals, firms, institutions, products, economies etc. - and their ties representing for example a familiar tie, cooperation agreements, commercial relations, 
consumption issues, among others. While the agents are graphically represented by a set of nodes or unit points, the ties are represented by lines with arrows pointing to the direction of the relationship when it is unidirectional.

In this paper we intend to use SNA to qualify the dynamic of HTE under a global context of exports flows for 2005 and 2015. For doing so, we will use some descriptive measures of connectivity and centrality so that we can identify the economies playing a central role in the exports networks, the flow dynamics and a comparative analysis in order to qualify the role of Latin America and the Caribbean within that network. These measures will be detailed in the following sections.

\subsection{Panel data}

The choice of the panel data methodology to analyze the determinants of HTE for LATAM and the Caribbean is explained by being the most used methodology in previous works as well as by the gain. This approach minimizes difficulties arising from endogeneity and allows the use of standard econometric techniques to obtain parameter estimation. This method can also control heterogeneity by allowing individuals-specific variables, provide more informative data, variability, efficiency, degrees of freedom, and less collinearity between variables.

Moreover, it is best in determining and measuring effects that are not determined simply by crosssection data or time series and provides important tools for examining how the variables or the relationship between them changes dynamically. "A longitudinal, or panel, data set is one that follows a given sample of individuals over time, and thus provides multiple observations on each individual in the sample. Panel model have become widely available in both the developed and developing countries" (HSIAO, 2007, p.1).

Formally, according to Baltagi (2005) and Hsiao (2007), the panel data model with fixed effects ${ }^{3}$ can be written as:

$$
Y_{i t}=x_{i t} \beta+c_{i}+e_{i t}
$$

where $Y_{i t}$ is the explained variable that varies with individuals $i$, which is the cross-section dimension and in time $t$, which is the dimension of time series, $x_{i t}$ discriminates the explanatory variables, $c_{i}$ is the individual effect or individual heterogeneity and is invariant over time, changing only from individual to individual and $e_{i t}$ is the idiosyncratic error that varies over time and between individuals. The modeling approach is considered to be fixed effects because the individual effect, $c_{i}$, does not change with the passage of time.

In order to comply with the cited objective of this work, a regression with panel data with fixed effects and robust standard errors will be estimated for the 20 countries of Latin America plus the Caribbean, from 2005 to 2015, using data from High Technology Exports (\% of manufactured exports), Labor Force with Advanced Education ( $\%$ of total working age population with advanced education), Foreign Direct Investment (FDI), as net inflows (\% of GDP), and Expenditures with R\&D (\% of GDP), available at World Bank - World Development Indicators.

\section{RESULTS AND DISCUSSION}

As an initial analysis, the overall picture of international trade on HTE is given by the trade networks for 2005 and 2015. Those networks were built by using annual imports data (in thousands of dollars) from the UNCTAD data center, which has as main data source the UN COMTRADE, that provides detailed raw trade data by partner and product. Trade networks are directed networks and they were built using imports data among other possibilities for the specification of the countries' links, as suggested by De Benedictis and Tajoli $(2011)^{4}$, which implies that the links go from the exporting country to the importing one. After the cleansing process we opted for considering 213 countries for both years ${ }^{5}$.

Networks' characterization is done analyzing changes in the connectivity density as well as in the centrality degrees. The density of a network measures the portion of potential ties in a network that actually

\footnotetext{
${ }^{3}$ The tests made to determinate the type of the panel data (pooled, fixed or random effects) are with the authors and can be requested at any time.

${ }^{4}$ The difference between imports (exports) and exports (imports) is mainly due to transport cost and insurance freight.

${ }^{5}$ Due to limitation of data availability.
} 
exist. Input and output degrees are measures of local connectivity and indicate the number of partners in terms of importers and exporters of a country. Finally, the weighted output degree takes into account the intensity of the ties; in this case it will represent the total exports of a country.

Based on our sample, the HTE networks presented a density of approximately $38 \%$ and $46 \%$ in 2005 and 2015, respectively, which is an indicator of a raise on the number of trading partners on average. It also may be interpreted as an increase in international economic integration due to a rising number of bilateral and regional preferential trade agreements, producing a higher degree of trade regionalization (Iapadre and Tajoli, 2014).

Centrality measures are presented in Table 1 and Table 2 for 2005 and 2015, respectively. From the first columns in both years we can highlight the predominance of Asian and European countries leading high tech exports with an intensification of the participation of Asian countries in 2015. Also, we can observe a high local density in the neighborhood of each country in the top 10 exporters; with the leaders presenting an output and input degree close to 200 which implies a local density of almost $100 \%$.

Moreover, looking to the weighted output degree (in relative values) in Table 1 we can see that in 2005 the top 10 countries together were responsible for $67,85 \%$ of the total amount of HTE, with United States and China leading them. Thus, a small percentage of the total number of flows accounts for most of the share of $\mathrm{HTE}^{6}$. In 2015 (Table 2), the top 10 countries were responsible for $69,85 \%$ of the total, but China expressively changed its position to the first place and almost doubled its relative participation.

Table 1: Top 10 countries based on total exports (no internal consumption) in 2005.

\begin{tabular}{ccccc}
\hline Country & ISO3 & Output Degree & Input Degree & Weighted Output Degree (\%) \\
United States & USA & 206 & 196 & 12,04 \\
China & CHN & 198 & 165 & 11,85 \\
Germany & DEU & 210 & 196 & 8,81 \\
Japan & JPN & 203 & 168 & 6,64 \\
Hong Kong & HKG & 184 & 140 & 5,69 \\
Singapore & SGP & 134 & 140 & 5,37 \\
South Korea & KOR & 197 & 167 & 4,71 \\
France & FRA & 208 & 192 & 4,29 \\
United Kingdom & GBR & 209 & 197 & 4,24 \\
Netherlands & NLD & 203 & 182 & 4,20 \\
\hline
\end{tabular}

Source: Data available at UNCTADStat, elaborated by the authors.

Table 2: Top 10 countries based on total exports (no internal consumption) in 2015.

\begin{tabular}{ccccc}
\hline Country & ISO3 & Output Degree & Input Degree & Weighted Output Degree (\%) \\
China & CHN & 203 & 188 & 21,83 \\
United States & USA & 207 & 200 & 8,49 \\
Hong Kong & HKG & 185 & 160 & 8,20 \\
Germany & DEU & 210 & 186 & 7,80 \\
South Korea & KOR & 201 & 189 & 4,76 \\
Singapore & SGP & 197 & 187 & 4,45 \\
France & FRA & 207 & 202 & 3,65 \\
Taiwan & TWN & 197 & 149 & 3,63 \\
Japan & JPN & 202 & 168 & 3,57 \\
Netherlands & NLD & 208 & 195 & 3,47
\end{tabular}

Source: Data available at UNCTADStat, elaborated by the authors.

\footnotetext{
${ }^{6}$ For a network with 213 nodes, a complete directed network would have 45,156 ties without considering loops.
} 
Regarding the main ties in the network structures, in 2005 and 2015, as we can see in Table 3, the most present countries when it comes to high tech exports flows are Hong Kong, China and United States. There is a shift in the position of Hong Kong and China when we considerer the destiny of the exports, but they remain as leaders, followed by United States. Together, these 10 countries are responsible for 18,53\% and 25,30\% in 2005 and 2015, respectively, of the total HTE amongst countries.

Table 3: Top 10 links amongst countries (2005 and 2015).

\begin{tabular}{ccc|ccc}
\hline \multicolumn{3}{c|}{2005} & \multicolumn{3}{c}{2015} \\
\hline From & To & Weighted Output Degree (\%) & From & To & Weighted Output Degree (\%) \\
HKG & CHN & 3,33 & CHN & HKG & 5,91 \\
CHN & HKG & 2,91 & HKG & CHN & 5,27 \\
CHN & USA & 2,59 & CHN & USA & 4,14 \\
MEX & USA & 2,20 & MEX & USA & 2,18 \\
USA & CAN & 1,55 & KOR & CHN & 1,93 \\
JPN & USA & 1,37 & USA & MEX & 1,46 \\
USA & MEX & 1,22 & CHN & KOR & 1,26 \\
KOR & CHN & 1,18 & CHN & JPN & 1,17 \\
DEU & FRA & 1,10 & USA & CAN & 1,00 \\
CAN & USA & 1,09 & DEU & USA & 0,99 \\
\hline
\end{tabular}

Source: Data available at UNCTADStat, elaborated by the authors.

Figures 1 and 2 show these ties, stating and confirming the information exposed in Table 3 and elucidating the relationship between Canada, United States and Mexico. Moreover, we see Singapore losing space, as well as United States having its size diminished and China augmented. These visualizations were achieved by filtering the weaker ties for a better visualization of the main HTE flows. Despite of the central role of China, US, Hong Kong, Singapore, The Netherlands, Canada and Germany, we must highlight the role of México and Brazil ${ }^{7}$ as bridges between central and peripherical countries in those structures.

\footnotetext{
${ }^{7}$ Brazil plays a role of local of supplier for South America and bridge for the whole region with Europe and Asia, although it doesn't appear in the maps due to the pruning of weaker links.
} 


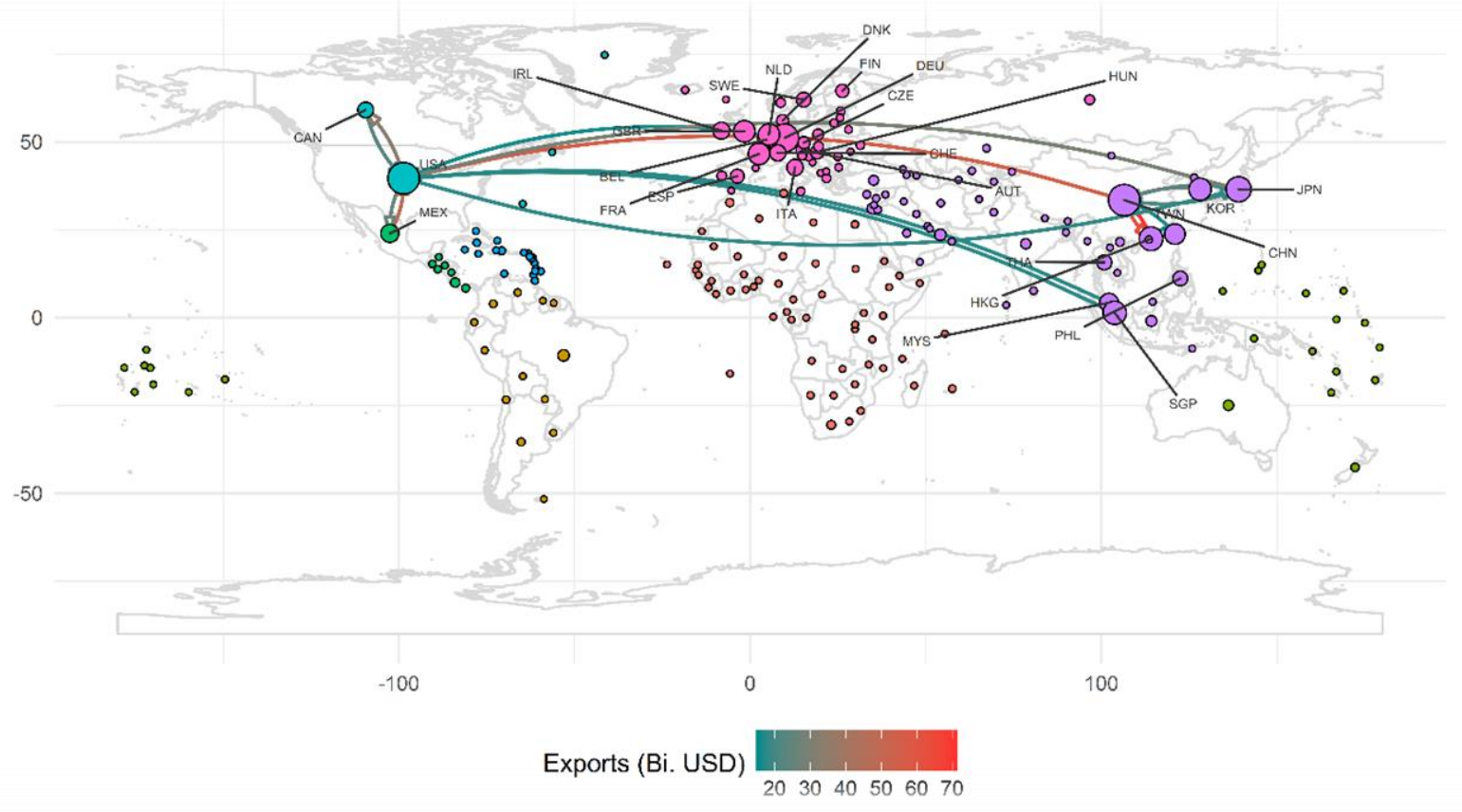

Figure 1: High tech exports links amongst countries in 2005.

Source: Data available at UNCTADStat, elaborated by the authors.

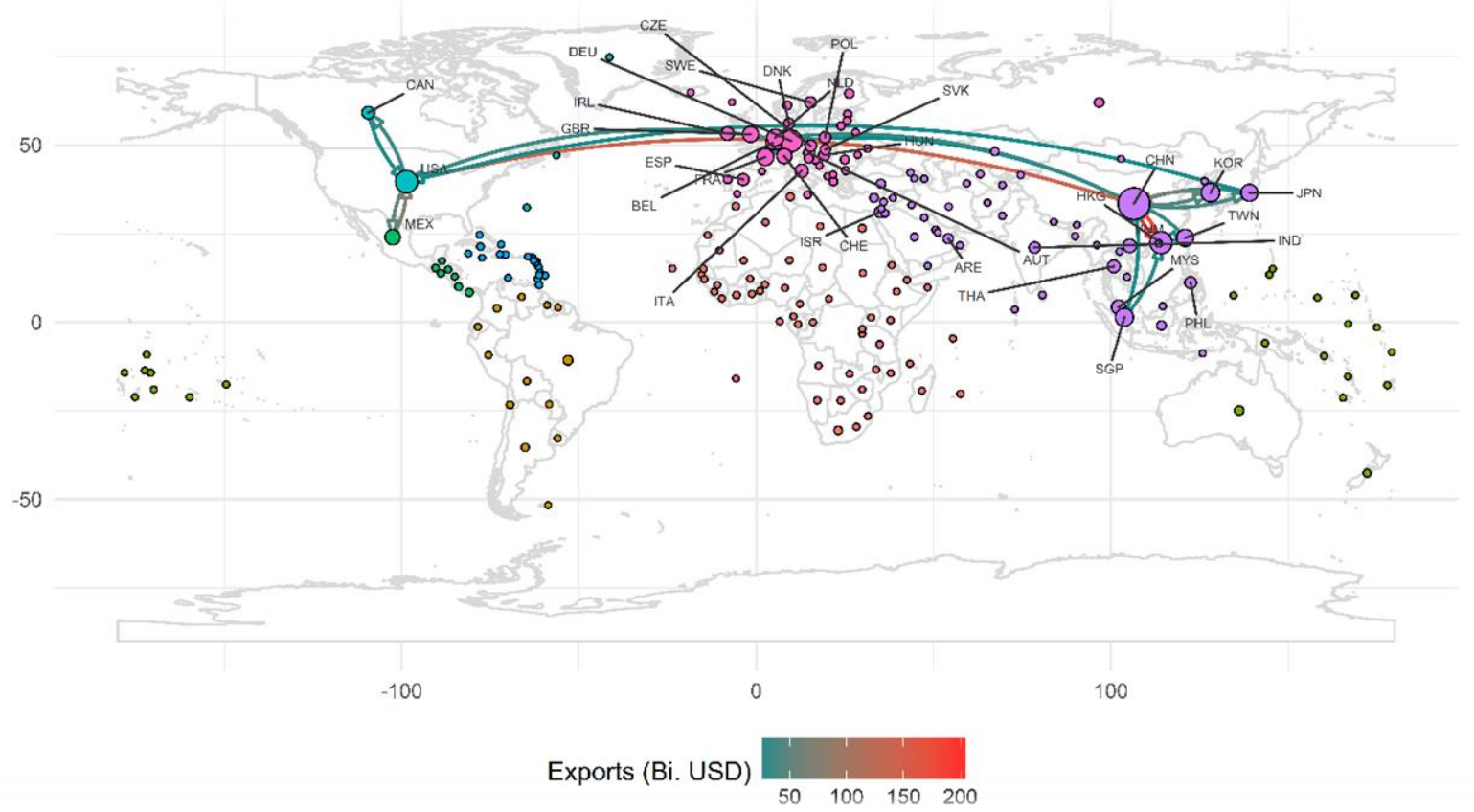

Figure 2: High tech exports links amongst countries in 2015.

Source: Data available at UNCTADStat, elaborated by the authors.

When we consider only Latin America countries plus Caribbean, the figure changes drastically. In 2005 (Table 4), the top 10 countries in Latin America together were responsible for only 3,24\% of the total high-tech exports, and in 2015 (Table 5) this relative participation dropped to 3,06\%. In 2005, Mexico leaded the group, but this changes in 2015 with Brazilian leadership. In terms of local density, we observe a lower average - closer to 100 than to 200 - if compared to the top exporters, however input and output centrality degrees of the central countries in the region presented an increase that is more significant for Mexico. From all the countries Argentina was the only one that kept its output degree at the same level in both years, although reveals a raise in its input degree (a higher number of HTE suppliers). Finally, from 
the ranking presented in both tables, in terms of high tech exports there is no significative change in the positions.

Table 4: Top 10 inside Latin America and Caribbean in 2005.

\begin{tabular}{cccccc}
\hline Country & ISO3 & Out Degree & In Degree & Ranking & Weighted Output Degree (\%) \\
Mexico & MEX & 150 & 145 & 14 & 2,51 \\
Brazil & BRA & 170 & 141 & 28 & 0,44 \\
Costa Rica & CRI & 128 & 92 & 41 & 0,14 \\
Argentina & ARG & 126 & 92 & 54 & 0,04 \\
Dominican Republic & DOM & 102 & 103 & 56 & 0,03 \\
Panama & PAN & 96 & 79 & 57 & 0,03 \\
Colombia & COL & 93 & 110 & 62 & 0,02 \\
Chile & CHL & 81 & 95 & 67 & 0,01 \\
El Salvador & SLV & 98 & 74 & 69 & 0,01 \\
Cuba & CUB & 90 & 90 & 76 & 0,01 \\
\hline
\end{tabular}

Source: Data available at UNCTADStat, elaborated by the authors.

Table 5: Top 10 inside Latin America and Caribbean in 2015.

\begin{tabular}{cccccc}
\hline Country & ISO3 & Out Degree & In Degree & Ranking & Weighted Output Degree (\%) \\
Mexico & MEX & 177 & 162 & 12 & 2,57 \\
Brazil & BRA & 177 & 164 & 34 & 0,28 \\
Panama & PAN & 119 & 98 & 50 & 0,06 \\
Argentina & ARG & 126 & 102 & 55 & 0,04 \\
Costa Rica & CRI & 137 & 133 & 59 & 0,03 \\
Colombia & COL & 102 & 136 & 62 & 0,03 \\
Chile & CHL & 89 & 122 & 68 & 0,02 \\
Cuba & CUB & 162 & 90 & 69 & 0,02 \\
Dominican Republic & DOM & 128 & 134 & 70 & 0,01 \\
Guatemala & GTM & 88 & 104 & 74 & 0,01 \\
\hline
\end{tabular}

Source: Data available at UNCTADStat, elaborated by the authors.

Using now the network technique for a regional and aggregate analysis, we can see how the participation of Latin America in high technology exports evolved throughout 2005 to 2015. From Figure 3, in 2005, we see an intense relationship between Central America and Asia, that comes from Central America and goes to Asia, which lost its strength in 2015 (Figure 4), with Europe and Africa gaining intensity in the volume of HTE, in a bilateral way.

It is important to notice that in 2015, when compared to 2005, the intensity of the relationship between South America and Europe gains strength, unilaterally coming from Europe, but Caribbean and Central America seems to be peripherical when it comes to high tech exports. 


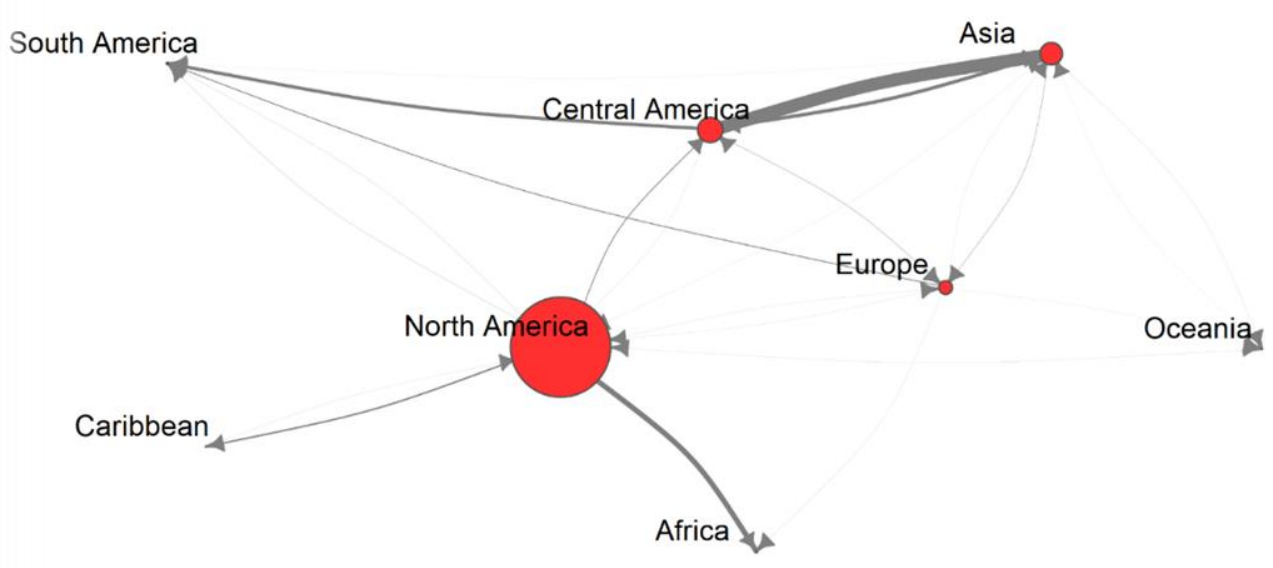

Figure 3: High technology exports in 2005.

Source: Data available at UNCTADStat, elaborated by the authors.

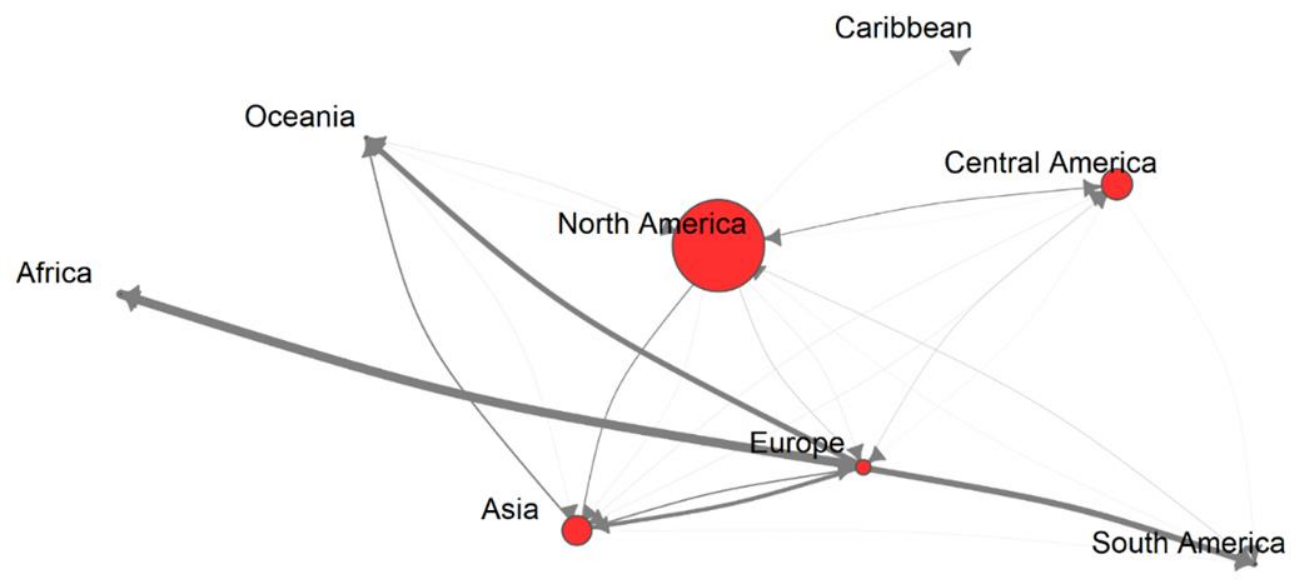

Figure 4: High technology exports in 2015.

Source: Data available at UNCTADStat, elaborated by the authors.

The Table 6 shows the relative participation of regions in 2005 and 2015, and as we can see, South America lost participation as well as Caribbean, but Central America augmented its share, mostly because Mexico (Tables 4 and 5) has its participation augmented during the period. Its relationship with United States and Canada is strong and became stronger in 2015 being the reason why Central America has significant participation on high tech exports. 
Table 6: Relative participation of Regions in total amount of high tech exports in 2005 and 2015.

\begin{tabular}{ccc}
\hline Regions & Weighted Output Degree (\%) \\
& $\mathbf{2 0 0 5}$ & $\mathbf{2 0 1 5}$ \\
Africa & 0,06 & 0,07 \\
South America & 1,36 & 1,23 \\
Oceania & 0,42 & 0,46 \\
Central America & 15,33 & 18,11 \\
North America & 60,90 & 53,96 \\
Caribbean & 0,09 & 0,07 \\
Asia & 13,55 & 17,25 \\
Europe & 8,28 & 8,85 \\
\hline
\end{tabular}

Source: Data available at UNCTADStat, elaborated by the authors.

This participation of Mexico in the export triad with USA and Canada can be seen in Table 7 with the augment of the relative weight between Central America and North America. The relationship between North America countries with North America countries is the biggest one, but lost participation during these 10 years of analysis. In 2005, these top 10 links were responsible for 93,25\% of the total amount of high tech exports, and in 2015 this percentage dropped to $92,6 \%$.

Table 7: Top 10 links amongst regions (2005 and 2015).

\begin{tabular}{|c|c|c|c|c|c|}
\hline \multicolumn{3}{|c|}{2005} & \multicolumn{3}{|c|}{2015} \\
\hline From & To & $\begin{array}{c}\text { Relative Weight } \\
(\%)\end{array}$ & From & To & $\begin{array}{c}\text { Relative Weight } \\
(\%)\end{array}$ \\
\hline North America & North America & 36,02 & North America & North America & 25,07 \\
\hline $\begin{array}{c}\text { Central } \\
\text { America }\end{array}$ & North America & 14,78 & $\begin{array}{l}\text { Central } \\
\text { America }\end{array}$ & North America & 17,42 \\
\hline North America & $\begin{array}{l}\text { Central } \\
\text { America }\end{array}$ & 9,80 & North America & $\begin{array}{l}\text { Central } \\
\text { America }\end{array}$ & 15,66 \\
\hline Asia & North America & 9,41 & Asia & North America & 11,25 \\
\hline North America & Asia & 5,90 & Europe & North America & 5,18 \\
\hline North America & Europe & 4,93 & North America & Asia & 4,80 \\
\hline Europe & North America & 4,61 & North America & Europe & 4,06 \\
\hline North America & South America & 2,79 & Asia & Asia & 3,61 \\
\hline Europe & Europe & 2,53 & North America & South America & 3,18 \\
\hline Asia & Asia & 2,48 & Europe & Europe & 2,37 \\
\hline
\end{tabular}

Source: Data available at UNCTADStat, elaborated by the authors.

Also, when we consider only the ties coming from Latin America countries, which means high tech exports that come from Latin America plus Caribbean to the world, what we see is an augment of the participation, $16,12 \%$ to $18,70 \%$, in 2005 and 2015 , respectively, but this happens manly because of the export triad Mexico - USA - Canada. 
Table 8: Top 10 links amongst Latin America countries plus Caribbean (2005 and 2015).

\begin{tabular}{|c|c|c|c|c|c|}
\hline \multicolumn{3}{|c|}{2005} & \multicolumn{3}{|c|}{2015} \\
\hline From & To & $\begin{array}{c}\text { Relative Weight } \\
(\%)\end{array}$ & From & To & $\begin{array}{c}\text { Relative Weight } \\
(\%)\end{array}$ \\
\hline $\begin{array}{l}\text { Central } \\
\text { America }\end{array}$ & $\begin{array}{c}\text { North } \\
\text { America }\end{array}$ & 14,78 & $\begin{array}{l}\text { Central } \\
\text { America }\end{array}$ & $\begin{array}{c}\text { North } \\
\text { America }\end{array}$ & 17,42 \\
\hline South America & $\begin{array}{c}\text { North } \\
\text { America }\end{array}$ & 1,00 & South America & $\begin{array}{c}\text { North } \\
\text { America }\end{array}$ & 0,93 \\
\hline $\begin{array}{l}\text { Central } \\
\text { America }\end{array}$ & Europe & 0,08 & $\begin{array}{l}\text { Central } \\
\text { America }\end{array}$ & Europe & 0,10 \\
\hline $\begin{array}{l}\text { Central } \\
\text { America }\end{array}$ & Asia & 0,08 & $\begin{array}{l}\text { Central } \\
\text { America }\end{array}$ & Asia & 0,08 \\
\hline Caribbean & $\begin{array}{l}\text { North } \\
\text { America }\end{array}$ & 0,07 & Caribbean & $\begin{array}{c}\text { North } \\
\text { America }\end{array}$ & 0,05 \\
\hline South America & Europe & 0,04 & $\begin{array}{l}\text { Central } \\
\text { America }\end{array}$ & Oceania & 0,04 \\
\hline $\begin{array}{l}\text { Central } \\
\text { America }\end{array}$ & Oceania & 0,02 & South America & Europe & 0,03 \\
\hline South America & Asia & 0,02 & South America & Asia & 0,02 \\
\hline South America & Oceania & 0,01 & South America & Oceania & 0,01 \\
\hline South America & Africa & 0,01 & Caribbean & Europe & 0,01 \\
\hline Caribbean & Europe & 0,00 & $\begin{array}{l}\text { Central } \\
\text { America }\end{array}$ & Africa & 0,01 \\
\hline $\begin{array}{l}\text { Central } \\
\text { America }\end{array}$ & Africa & 0,00 & South America & Africa & 0,01 \\
\hline Caribbean & Asia & 0,00 & Caribbean & Asia & 0,00 \\
\hline Caribbean & Oceania & 0,00 & Caribbean & Africa & 0,00 \\
\hline Caribbean & Africa & 0,00 & Caribbean & Oceania & 0,00 \\
\hline
\end{tabular}

Source: Data available at UNCTADStat, elaborated by the authors.

The following Graphics 1 to 3 explore the evolution over time of High Tech Exports, R\&D Expenditures and FDI Expenditures, as net inflows in Latin America and the Caribbean, with aggregated data available from World Bank - World Development Indicators. Exports of products with high aggregate technology have been declining over time, which may indicate a specialization of these countries in other manufactured activities.

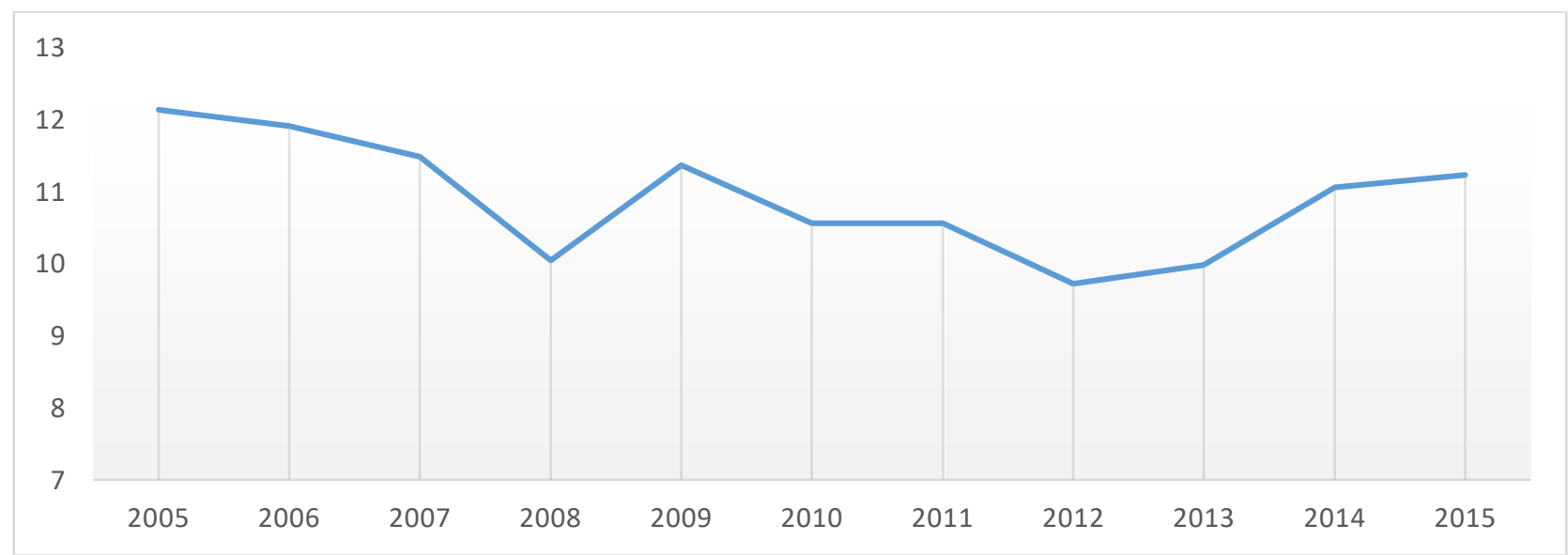

Graphic 1: High Technology Exports from Latin America and the Caribbean (\% of manufactured exports) - 2005 to 2015.

Source: World Bank, World Bank Development Indicators, 2005 to 2015. 
On the other hand, R\&D expenditure has been increasing over time, which shows the efforts of the countries with the generation of innovative products, probably within the manufactured products in which they are specializing.

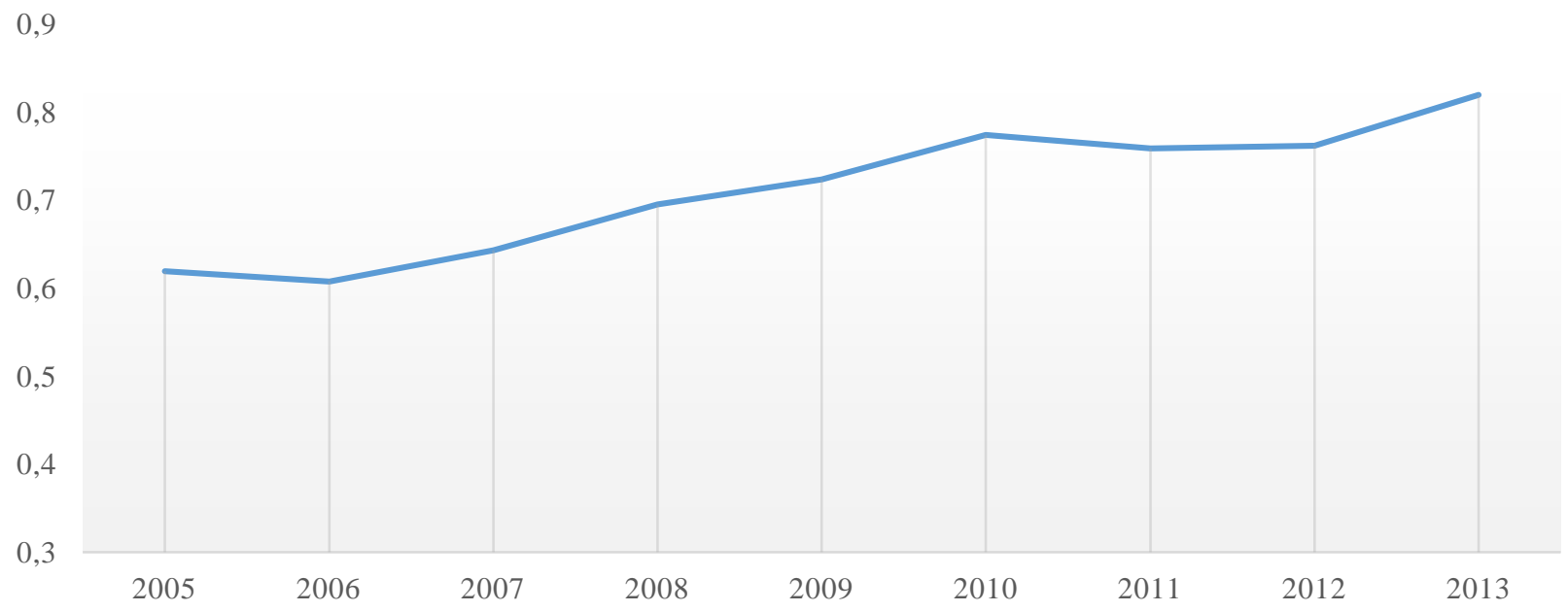

Graphic 2: R\&D Expenditures from Latin America and the Caribbean (\% of GDP) - 2005 to 2013. Source: World Bank, World Bank Development Indicators, 2005 to 2013.

The variable with higher volatility seems to be FDI, which has been interspersed with periods of increase and fall, with a tendency to increase in the most current years. This variable will also be used in an attempt to explain the determinants of high technology exports in Latin America and the Caribbean.

4,5

3,5

2,5

1,5

0,5

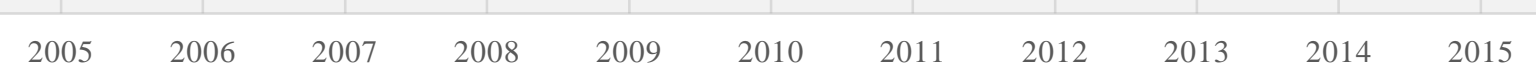

Graphic 3: Foreign direct investment, net inflows, Latin America and the Caribbean (\% of GDP) - 2005 to 2015.

Source: World Bank, World Bank Development Indicators, 2005 to 2015.

In order to analyze potential determinants of HTE for Latin America and the Caribbean, a regression on panel data with fixed effects is estimated with the logging of high technology exports as a function of the $\log$ of foreign direct investment, $\log$ of R\&D expenditures and labor force with advanced education, divided into three models. The results of the estimated models with robust standard errors are set out in Table 9 below. 
Table 9: Results of panel data analysis with fixed effects for high technology exports.

\begin{tabular}{|c|c|c|c|}
\hline & $(1)$ & $(2)$ & $(3)$ \\
\hline \multirow[t]{2}{*}{ FDI } & $-0,2538 *$ & $-0,0788$ & $-0,1257$ \\
\hline & $(0,091)$ & $(0,250)$ & $(0,558)$ \\
\hline \multirow[t]{2}{*}{ Constant } & $1,8631 * * *$ & $2,7517 * * *$ & $2,3071 * *$ \\
\hline & $(0,000)$ & $(0,004)$ & $(0,027)$ \\
\hline \multirow[t]{2}{*}{ R\&D Expenditures } & & 0,5519 & $2,4114 * * *$ \\
\hline & & $(0,368)$ & $(0,150)$ \\
\hline \multirow[t]{2}{*}{ Labor Force with Advanced Education } & & & $0,0354 *$ \\
\hline & & & $(0,095)$ \\
\hline $\mathrm{N}$ & 195 & 99 & 50 \\
\hline Rô & 0,5209 & 0,6247 & 0,9680 \\
\hline p-value $(F)$ & 0,0914 & 0,1557 & 0,2834 \\
\hline $\mathrm{R}^{2}$ overall & 0,0148 & 0,2398 & 0,2103 \\
\hline
\end{tabular}

Source: Research results.

Standard errors in parentheses. * indicates significance at the 10 percent level. ** indicates significance at the 5 percent level. *** indicates significance at the 1 percent level.

The three models confirm that, statistically, inflows of foreign direct investment into the 20 countries of Latin America plus the Caribbean are not significant for explaining the growth of high technology exports. However, only the first model is globally significant at $10 \%$, given p-value $(\mathrm{F})$ of 9.14\%. However, although it is globally significant, the only variable inserted in the model is not significant.

The results do not seem to corroborate completely with the empirical studies presented in section 2 of this work. The FDI has not shown to be significant, which is contrary to the results obtained for the other countries. R\&D expenditures and labor force with advanced education as a proxy for qualified human capital have results that corroborate those of Tebaldi (2011) and Braunerhjelm and Thulin (2008), but the models in which they were inserted are not globally significant. These results may indicate that the countries of Latin America and the Caribbean have a differentiated dynamic in relation to the developed countries, presenting a differentiated export agenda. Non-significance also has a meaning, that is, understanding why these variables are not significant is also part of the analysis.

However, as challenged by Tigre (1989), policymakers must understand whether and to what extent countries should promote the development of endogenous technology. "Under usual conditions, this requires direct government investment in $\mathrm{R} \& \mathrm{D}$, as well as incentives and protection from the technology that comes from abroad", and there would be an alternative," other than relying heavily on external investment and technology" (TIGRE, 1989, p.219). More than this, the author affirms that the Latin American high-tech industry has important determinants like FDI and licensing practices and cooperation in technology.

It is known that investment requires maturation time, as well as the benefits of R\&D expenditure in companies, even if it is selective or adaptive R\&D. "An analysis of perspectives is necessarily historical. The past is projected onto the future, and although it does not determine it, it conditions it "'" (ERBER, 2000, p.181). Moreover, the results of these past efforts "may require long maturation time, are uncertain and their economic suitability by the organization is low"10 (Idem, p.184).

In this sense, in an attempt to absorb the passage of time in the maturation of the efforts of the determinants of high technology exports, a model is proposed that captures the lag of both FDI and R\&D expenditures and the labor force with advanced education in an attempt to approximate the results of those found by Tebaldi (2011), which uses the lagged variables in a period in its modeling. The results of this model (4) estimated with robust standard errors can be seen in Table 10 below.

\footnotetext{
${ }^{8}$ Translation made by the authors.

${ }^{9}$ Translation made by the authors.

${ }^{10}$ Translation made by the authors.
} 
Table 10: Results of panel data analysis with fixed effects for high technology exports with lagged variables.

\begin{tabular}{|c|c|c|}
\hline & \multicolumn{2}{|r|}{ (4) } \\
\hline & FDI - 1 & $\begin{array}{l}-0,0231 \\
(0,778)\end{array}$ \\
\hline & Constant & $\begin{array}{l}1,8830 * * * \\
(0,001)\end{array}$ \\
\hline & R\&D Expenditures -1 & $\begin{array}{c}1,5186^{* *} \\
(0,037)\end{array}$ \\
\hline & Labor Force with Advanced Education - 1 & $\begin{array}{c}0,0247 * * \\
(0,016)\end{array}$ \\
\hline & $\bar{N}$ & 50 \\
\hline & Rô & 0,9772 \\
\hline & p-value $(F)$ & 0,0582 \\
\hline & $\mathrm{R}^{2}$ overall & 0,2140 \\
\hline
\end{tabular}

Source: Research results.

Standard errors in parentheses. $* *$ indicates significance at the 5 percent level. $* * *$ indicates significance at the 1 percent level.

The results of model (4) show that two of the three lagged explanatory variables remain significant. The labor force with advanced education, significant at 5\%, carries the greatest weight in explaining the variation of high-tech exports, as supposed by the Graph 1, with the increase in one unit in the number of labor force at time $t-1$ increases exports by 2.4 percentage points. Lapsed R\&D expenditures, significant at $5 \%$, also explain the variation in high technology exports, with a $1 \%$ increase in these expenditures at time $t-1$ increasing exports by 1.51 percentage points. However, past foreign direct investment does not seem to affect changes in high technology exports.

What may explain these results is either a change in the configuration of the Latin American economy or the need for a better specification of the models to be estimated. But for the first option, which is the possible change in the configuration of the Latin America economy, when it comes to HTE it is viable to infer that, according to what was exposed when it was analyzed the network that exist between countries, it hasn't happened. This study sought to replicate, in part, what literature has already been doing for developed countries and, as we know, the reality as well as the structure of the economy of developed and developing countries are quite different, so that a variable that is extremely significant in one configuration may not be in the other.

\section{CONCLUDING REMARKS}

This work has sought, to a certain extent, to replicate the ideas of previous studies carried out for developed countries for the countries of Latin America and the Caribbean, in order to find the determinants of high technology exports for the countries analyzed. When we analyzed the performance of countries inside the network constructed between them, we could see that Latin America and Caribbean has a minority role, with Mexico leading the group mostly because of its relationship with United States and Canada. The results of the research indicate that a better approach to the determinants is considered to be out of phase in a period, as done by Tebaldi (2011). The model (4) presented in the previous section indicates that R\&D expenditures and the labor force with advanced education in period $t-1$ explain the variations in high technology exports, but the FDI in t-1 is not of significant importance in the explanation of HTE.

In a way, this shows both the maturation of expenditures and its influence in the current period, and that structural differences between developing and developed countries are manifested in the different determinants of the different variables analyzed. This opens space for the formulation of a more Latin American specific model, that is, that takes into account the specific structural conditions of the countries analyzed in order to find what really impacts high technology exports. This, however, is a goal for future work. 


\section{REFERENCES}

BALASSA, B. Exports and economic growth: further evidence. Journal of development Economics, $v$. 5, n. 2, p. 181-189, 1978.

BAltaGi, B. Econometric Analysis of Panel Data. 2005.

BRAUNERHJELM, P.; THULIN, P. Can countries create comparative advantages? R\&D expenditures, high-tech exports and country size in 19 OECD countries, 1981-1999. International Economic Journal, v. 22, n. 1, p. 95-111, 2008.

DE BENEDICTIS, L.; TAJOLI, L. The World Trade Network. The World Economy, 34: 1417-1454. doi:10.1111/j.1467-9701.2011.01360.x, 2011.

ERBER, F. S. Perspectivas da América Latina em ciência e tecnologia. Parcerias estratégicas, v. 5, n. 8, p. 181-200, 2009.

ESFAHANI, H. S. Exports, imports, and economic growth in semi-industrialized countries. Journal of Development Economics, v. 35, n. 1, p. 93-116, 1991.

FALK, M. High-tech exports and economic growth in industrialized countries. Applied Economics Letters, v. 16, n. 10, p. 1025-1028, 2009.

FUNG, K. C.; CHEN, L.; GARCIA-HERRERO, A. Determinants of trade in parts and components: Latin America and East Asia. Journal of Chinese Economic and Foreign Trade Studies, v. 9, n. 3, p. 245 $252,2016$.

GÖKMEN, Y.; TUREN, U. The determinants of high technology exports volume: A panel data analysis of EU-15 countries. International Journal of Management, Economics and Social Sciences, v.2, n.3, p. 217-232, 2013.

HSIAO, C. Analysis of panel data. Cambridge University Press, 2007.

IAPADRE, P. L.; TAJOLI, L. Emerging countries and trade regionalization. A network analysis. Journal of Policy Modeling, v. 36, p. S89-S110, 2014.

JACKSON, M. O. Social and Economic Networks. Princeton University Press, 2010.

JUNG, W. S.; MARSHALL, P. J. Exports, growth and causality in developing countries. Journal of development economics, v. 18, n. 1, p. 1-12, 1985.

SARA, T. S. et al. Role of innovation in hi-tech-exports of a nation. International Journal of Business and Management, v. 7, n. 7, p. 85, 2012.

SCOTT, J. Social Network Analysis. Sociology, v. 22, n. 1, 1988.

SERRAT, O. Social Network Analysis. In: Knowledge Solutions. Springer, Singapore, p. 39-43, 2017.

SEYOUM, B. The role of factor conditions in high-technology exports: An empirical examination. The journal of high technology management research, v. 15, n. 1, p. 145-162, 2004. 
Determinants of levels of high technology exports an empirical investigation. Journal of Competitiveness Studies, v. 13, n. 1, p. 64, 2005.

TEBALDI, E. The determinants of high-technology exports: A panel data analysis. Atlantic Economic Journal, v. 39, n. 4, p. 343-353, 2011.

TIGRE, P. B. Como a América Latina se enquadra na alta tecnologia? Ensaios FEE, v. 10, n. 2, p. 212 224, 1989. 